\title{
Application of Mina Padi in Lidah Tanah Village, Perbaungan District, Serdang Bedagai Regency
}

\author{
M.Yusuf Dibisono, Rini Sulistiani, A.Syafri, Syarifa Mayly ${ }^{1 *}$ \\ ${ }^{1}$ Program Study of Agroecotechnology, Faculty of Agriculture, Universitas Al Wasliyah, Medan
}

\begin{abstract}
Berkat" and "Serasi" Farmers Group are farmer groups located in Lidah Tanah Village, Perbaungan District. There are various problems found in the two farmer groups, which are: (a) Low / limited farmer income, (b) Increasing pests and diseases attack, (c) Unfamiliarity about "Mina Padi Lele" cultivation system and do not implement it to increase their income, to optimize land, to reduce pest and weed attacks, to increase the efficiency of fertilizers and water usage, (d) Farmers do not know and do not implement routine pest monitoring systems, (e) Farmers have no knowledge about organic pesticides production, (f) Farmers have no knowledge about organic feed production for catfish cultivation and (g) Environmental pollution due to excessive use of pesticides and less utilization of harvest waste such as rice straw. The solution to overcome these various problems is by applying "Mina Padi Lele" technology, which is a farming system by combining the techniques of rice cultivation and raising fish simultaneously in paddy fields. The results showed that the application of the "Mina Padi Lele"cultivation system greatly benefited farmers, where organic rice produced from the "Mina Padi Lele"system was $263.5 \mathrm{~kg} / 400$ $\mathrm{m}^{2}$ with additional $57.5 \mathrm{~kg} / 400 \mathrm{~m}^{2}$ of organic catfish products while non-organic rice produced from cultivation conventionally applied by farmers is $257.6 \mathrm{~kg} / 400 \mathrm{~m}^{2}$.
\end{abstract}

Keywords: Mina padi lele, Organic pesticides, Bokashi, Organic feed

Abstrak. Kelompok Tani "Berkat" dan Kelompok Tani "Serasi" merupakan kelompok tani yang terdapat di Desa Lidah Tanah Kecamatan Perbaungan. Berbagai permasalahan yang dapat diidentifikasi dari kedua Mitra yaitu: (a) Pendapatan petani rendah/terbatas,(b) serangan hama dan penyakit yang cenderung meningkat dari tahun ke tahun, (c) petani belum mengetahui dan menggunakan sistem budidaya mina padi untuk meningkatkan pendapatan petani, optimalisasi lahan, serta menurunkan serangan hama penyakit dan gulma, serta meningkatkan efisiensi penggunaan pupuk dan air, (d) petani belum mengetahui dan menggunakan sistem monitoring hama secara rutin, (e) petani belum mengetahui cara pembuatan 
pestisida organik, $(f)$ petani belum mengetahui cara pembuatan pakan organik untuk budidaya lele,dan (g), masalah pencemaran lingkungan akibat penggunaan pestisida yang berlebihan dan kurang memanfaatkan limbah panen seperti jerami padi.Solusi untuk mengatasi permasalahan ini adalah dengan Penerapan Teknologi Mina Padi Lele, yaitu system pertanian yang menggabungkan Teknik budidaya padi dan pemeliharaan ikan sekaligus di lahan pertanaman padi. Hasil kegiatan menunjukkan aplikasi system budidaya Mina Padi lele budidaya mina padi lele sangat menguntungkan petani, dimana beras organik yang yang dihasilkan dari sistem mina padi lele sebanyak 263,5 kg/rante ditambah produk lele organik sebanyak 57,5 kg/rante sedangkan beras non organik yang dihasilkan dari budidaya konvensional yang diterapkan oleh petani yaitu $257,6 \mathrm{~kg} /$ rante.

Kata Kunci: Mina padi lele, Pestisida organik, Bokashi, Pakan organik Received 25 November 2018 | Revised 1 April 2019| Accepted 15 April 2019

\section{Introduction}

Serdang Bedagai Regency has an area of 1,900.22 km2 (190,022 Ha) consisting of 17 Subdistricts and 243 Villages. Serdang Bedagai Regency is geographically located at position 2057 ' N, 3016 ' S, 98033 " - 990 27' E and 0 - 500 meters above sea level (BPS Sergai, 2013). Serdang Bedagai Regency is the center of the main producer of rice in North Sumatra with a harvested area of rice fields of 68,494 ha in 2012, rice production of 369,599 tons and average production of 5,396 tons/ Ha. Serdang Bedagai Regency has a total area of irrigated paddy fields of 35,614 ha consisting of 9,943 ha of technical irrigated rice fields, 20,396 ha of semi-technical irrigated rice fields, and 5,275 ha of simple irrigated rice fields. Based on data from BPS Sergai [1], Perbaungan Sub district, which is the center for paddy rice cultivation in Serdang District, it has a harvested area of rice fields of 12,616 ha in 2012, rice production of 69,897 tons, average production of $55.40 \mathrm{KW} / \mathrm{Ha}$ and extensive technical irrigated rice fields amounting to 5,395 ha.

Some of the problems in North Sumatra's food crops include pest attacks which has been increasing by around $30 \%$. The biggest pest and disease attacks consisted of several types of mice, followed by rice leaf roller moth, mulberry snails, rice black bugs, rice ear bugs, Asian rice gall midge, brown plant hopper (Nilaparvata lugens), birds, blast, bacterial leaf blight (Xanthomonas oryzae) / crackers, BRS (bacterial red stripe) and Rice Tungro Bacilliform Virus. These problems also occurs in Serdang Bedagai Regency. 
"Berkat" Farmers Group and "Serasi" Farmers Group are farmer groups located in Lidah Tanah Village, Perbaungan District. The "Berkat" farmer group was revitalized with the Decree of the Head of Tongah Tanah Village Number 30 in 2016. The Berkat farmer group consists of 135 members with 30 ha of rice fields and 5 ha of dry land. The "Serasi" farmer group is also located in Lidah Tanah Village, Perbaungan Sub district consists of 89 farmers with 27 ha of rice field area and 3.5 ha dry land area.

There are various problems found in the two farmer groups, which are: (a) Low / limited farmer income, (b) Increasing pests and diseases attack, (c) Farmers are not familiar about "Mina Padi Lele" cultivation system and do not implement it to increase their income, to optimize land, to reduce pest and weed attacks, to increase the efficiency of fertilizers and water usage, (d) Farmers do not know and do not use routine pest monitoring systems, (e) Farmers have no knowledge about organic pesticides production, (f) Farmers have no knowledge about organic feed production for catfish cultivation and (g) Environmental pollution due to excessive use of pesticides and less utilization of harvest waste such as rice straw.

Based on the discussions with the two farmer groups, the solution offered in order to overcome their problems is the application of "Mina Padi Lele" technology, which is a farming system that combines rice cultivation and fish-raising techniques simultaneously in paddy fields. Mina padi lele can provide multiple benefits to farmers, namely rice yields as the main crop and harvesting fish of a certain size per planting season. Utilization of rice fields as a place for rice cultivation as well as a place for fish farming are feasible because the maintenance of the two commodities is complementary and does not interfere each other [2].

Catfish is one of the freshwater fish that has an important economic value and high nutrient content. Some of the benefits that can be obtained from mina catfish are as followed: it does not reduce rice production, it increases farmers' income from selling catfish, it is able to protect rice plants from rats, it reduces attacks of snails and leafhoppers that disrupt rice productivity, it reduces the use of chemical fertilizers and pesticides, it does not require extraland area which has been provided from existing rice fields [3].

Catfish is one of the freshwater fish that has an important economic value. The nutritional content of catfish per 100 grams includes $17.0 \mathrm{~g}$ protein, $4.5 \mathrm{~g}$ fat, $20 \mathrm{mg}$ calcium, $200 \mathrm{mg}$ phosphorus, $1.0 \mathrm{mg}$ iron, $150 \mathrm{IU}$ vitamin A, $0.05 \mathrm{IU}$ vitamin B. Catfish 
is good for toddlers because they contain high protein, bone strengthening substances (calcium), and other minerals that are important for the health of the body [4].

Catfish production increased by $47.21 \%$ in the period of 2010 to 2013, but it still falls below the annual target. This happened due do the business capacity in catfish cultivation is still running on a small scale. Therefore, it is economically inefficient and also it leads to high production costs due to the high price of the catfish feed. In 2011, Indonesia dominated world catfish production with a share of around $75.6 \%$ compared to total world catfish production, followed by Malaysia with a share of $10.5 \%$ [4].

Some of the benefits that can be obtained from mina lele are as followed: it does not reduce rice production, it increases farmers' income from selling catfish, it is able to protect rice plants from rats, it reduces attacks of snails and leafhoppers that disrupt rice productivity, it reduces the use of chemical fertilizers and pesticides, it does not require extra land area which has been provided from existing rice fields. Mina Padi with tilapia, goldfish, and shrimp, do not prevent rice fields from rat attack. Whereby, Mina Padi with catfish protects the rice field from the attack. The use of catfish in mina padi as a method to control pest is quite significant, because catfish is a type of carnivorous fish and nocturnal. The choice of catfish for Mina Padi is due to the fact that it can be cultivated in limited water sources with high stocking densities, catfish cultivation is also easily understood by the community, relatively easy to market, and lower business capital. In addition, catfish cultivation is easier because catfish can eat tiny animals, such as water lice, larvae (larvae, insects), small snails, and others. Catfish will not faceany difficulty in finding its food, so it has higher survival rate [5].

This activity aims to increase the income of farmers with catfish mina technology, to increase farmers' knowledge about integrated pest control, healthy rice cultivation, making organic feed, compost and organic pesticides.

\section{Method}

The community service activities are carried out with the following stages and methods:

1. Situation Analysis

Situation analysis was carried out on the problems faced by the farmer groups and was further explored by conducting interviewswith members of the farmer groups. After an inventory of problems, then the implementers and farmer groups agreed to focus on a problem that was urgent and in dire need of a solution. The problem that 
was agreed upon was regarding the application of MinaPadi Lele technology on farmers' land.

2. Solutions offered to solve farmer group's problems

The problem that was agreed upon was regarding the application of Mina Padi Lele technology on farmers' land. Therefore, the implementer offered a solution that includes creating MinaPadi Lele demonstration plots, counseling and training on the application of MinaPadi Lele, producing bokhashi, organic pesticides, organic feed, azolla propagation, and applying the principle of integrated pest management (IPM) to farmers' land.

3. Implementation of activities at the farmer group's locations

Implementers and partners both agree to determine the timing of activities at partner locations. The partners participate by preparing the location of the activity, inviting members of other farmer groups, preparing the materials needed for the implementation of services in accordance with the agreement that has been set. While the organizers prepared counseling materials about the technology of applying MinaPadi Lele.

4. Evaluate the success of the activity

Evaluation of the activities was carried out at the end of the activity after it had been completed in order to observe the service activities result and the impact of the activities for farmers.

\section{Result and Discussion}

Stages of activities in the PKM Implementation of Mina Padi Lele in Lidah Tanah Village, Perbaungan Subdistrict, Serdang Bedagai District were carried out as followed: Counseling and Training in the Production of Corynebacterium and Trichoderma-based Organic Pesticides, Extension and Training for the Production of Bokashi Compost Fertilizer, Azolla Propagation Training, Counseling about Mina Padi Lele and Demonstration of Mina Padi Lele Plots, Organic Feed Production Training, Counseling of Integrated Pest Control.

a. Counseling and Training in Production of Corynebacterium and

\section{Trichoderma-based Organic Pesticides}

The results achieved were farmers who attended the counseling and training activities understand the process of corynebacterium and Trichoderma based pesticides production, how to control crackles with corynebacterium and 
Trichoderma based pesticides and their application in the field and products from corynebacterium and Trichoderma based pesticides.

\section{b. Counseling and Training on Producing Compost from Hay (Bokashi) Fertilizer}

The results achieved were farmers who attended the counseling and training activities understand the importance of bokashi fertilizer and how to produce bokhashi fertilizer with local microorganisms and the products in the form of organic bokashi fertilizer.

c. Azolla sp. Propagation Training

The results achieved were farmers who attended the extension and training activities understand the importance of using azolla as an alternative fertilizer on the mina padi system and azolla propagation in bucket as a media.

\section{d. Counseling about Mina Padi Lele and Demonstration of Mina Padi Lele Plots}

The results achieved were farmers who attended the counseling and training activities understand the stages of activities in the Mina Padi Lele system and to implement it directly in the $800 \mathrm{~m} 2$ size demonstration plot and the products resulted were organic rice and catfish. In the Mina Padi Lele system, organic rice is produced at $263.5 \mathrm{~kg} / 400 \mathrm{~m}^{2}$ which is higher than the rice produced by conventional cultivation applied by farmers, at around $257.6 \mathrm{~kg} / 400 \mathrm{~m}^{2} \mathrm{In}$ the mina padi system, additional products such as catfish are produced as much as $57.5 \mathrm{~kg} / 400 \mathrm{~m}^{2}$ so that the Mina Padi Lele cultivation system is feasible.

e. $\quad$ Organic Feed Production Training.

The results achieved were farmers who attended the training activities to find out how to produce catfish organic feed and organic catfish feed were produced.

\section{f. Counselling of Integrated Pest Management}

The results achieved were farmers who were present in the counselling activities understand the principles of integrated pest control in rice cultivation.

The output of this PKM has resulted in several products, namely organic pesticides made from Corynebacterium and Trichoderma, straw-based fertilizers, organic rice and catfish, catfish organic food and certificates for partner farmers who have participated in counseling and training in application of Mina Padi Lele.

\section{Conclusion}

The Mina Padi Lele cultivation system is very beneficial for farmers, this can be seen from the yield of rice produced from the Mina Padi Lele system $\left(263.5 \mathrm{~kg} / 400 \mathrm{~m}^{2}\right)$ which is higher than the conventional cultivation applied by farmers, namely 257.6 
$\mathrm{kg} / 400 \mathrm{~m}^{2}$. In addition, the Mina Padi Lele system also produces additional products, namely catfish as much as $57.5 \mathrm{~kg} / 400 \mathrm{~m}^{2}$ so that the Mina Padi Lele cultivation system is feasible to apply.Products resulted from these activities include products in the form of organic pesticides made from Corynebacterium and Trichoderma, rice straw products that have been composted with local microorganisms (bokashi), products in the form of organic rice, catfish organic feed products and certificates for farmer groups who have participated in counseling and training in community service.

\section{Acknowledgement}

On this good occasion we would like to express our deepest gratitude to: The General Director of Higher Education who has funded this research through the Science and Technology Service program for the community, the Coordinator of Kopertis I NAD-SUMUT, the Chancellor and the Chairperson of the UNIVA Research Center for opportunities and facilities provided.

\section{References}

[1] Abbas, S. 2004. Making of Cathfish Sale . Yogyakarta: Kanisius.

[2] Statistics of Serdang Bedagai Regency. 2019. Sergai Utara in Numbers 2019.

[3] Directorate General of Fisheries Farming, Ministry of Marine Affairs and Fisheries Republic of Indonesia. 2013. Annual Report, Production Directorate in 2013.

[4] Directorate General of Fisheries Farming, Ministry of Marine Affairs and Fisheries Republic of Indonesia. 2011. General Guidelines for "Mina Padi", Jakarta.

[5] Hasanah, Y., Hanum, H., dan Rusmarilin, H., 2016. Application of Organic Mina Rice Vegetable Cultivation System in Supporting Food Security. Abdimas Talenta 1 (1) 2016: 1-4http://jurnal.usu.ac.id/abdimas.

[6] Lestari, S., Rifai, M., 2017. Rearing Catfish Together with Rice (Mina Padi) As A Potential Profit Multiplied for Farmers. Jurnal Terapan Abdimas, Volume 2, Januari 2017, hlm. 27-32. 